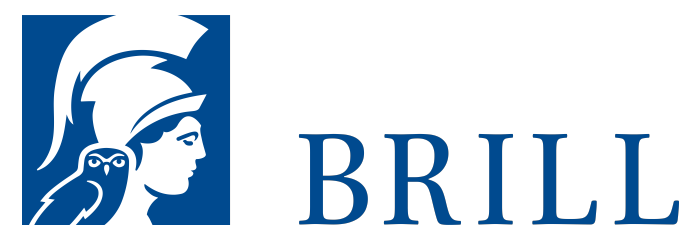

\title{
Multimediale Aufführungskunst
}

Medienästhetische Studien zur Entstehung einer neuen Kunstform

Author: Christiane Heibach

Die multimediale Theateraufführung ist eine der ältesten Kunstformen der Welt; doch als der Prozess der Bildung eines autonomen Kunstsystems um 1800 seinen Höhepunkt findet, gehört sie nicht zu den Künsten, denen eine rein ästhetische Existenzberechtigung zugesprochen wird. Erst ca. 100 Jahre später, zu Beginn des 2o. Jahrhunderts, wird auch sie als autonome Kunstform langsam anerkannt. Christiane Heibach macht sich auf die Spurensuche nach den Gründen für diese verspätete Entwicklung: Ihr Buch geht den Verschiebungen in den ästhetischen Diskursen von 1800 bis in die 2oer Jahre des 2o. Jahrhunderts nach und zeichnet ein komplexes Bild der medienästhetischen Bedingungen, die zur Anerkennung der Aufführung als autonome Kunstform führen.

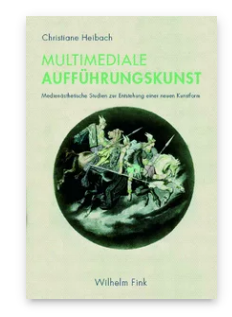

Pages: 376

Seiten, $14 \mathrm{~s} / \mathrm{w}$

Abb.

Language:

German

Publisher: Brill |

Fink

E-Book (PDF)

Released online:

29Jan 2020

ISBN: $978-3^{-}$

8467-4899-2

List price

USD $\$ 40.00$

Paperback

Publication date:

18 Nov 2009

ISBN: 978-3-

7705-4899-6

List price

USD $\$ 40.00$ 
For more information see brill.com

Order information: Order online at brill.com +44330 333 0049 | customerservices@brill.com Submission information: brill.com/authors

Titles published by Brill | Fink, Brill | mentis or Brill | Schöningh: +49(o)715413279216| brill@brocom.de 